\title{
HUMAN GROWTH NEW PARADIGM SEBAGAI STRATEGI PENGEMBANGAN SUMBERDAYA MANUSIA (SDM) INDONESIA
}

\author{
Misbahuddin \\ PPS MM STIM LPI Makassar (misbahuddin42@yahoo.com)
}

\begin{abstract}
ABTRAK
Tulisan ini didasarkan pada dua teori yang mempertegas tentang paradigma bagaimana peran pendidikan bagi pembangunan. Yang pertama, adalah paradigma sumber daya manusia (human capital paradigm), yang dipengaruhi oleh teori ekonomi klasik, Neo Liberal. Teori ini memandang dan menempatkan sumber daya manusia hanya sebagai faktor produksi. Yang kedua adalah paradigma yang berorientasi pengembangan SDM dengan arah tujuan jangka panjang, yaitu human growth paradigm. Merupakan suatu paradigma yang membangun SDM dengan sistem pendidikan yang bukan hanya mengandalkan kecerdasan intelektual (knowledge) serta keterampilan psikomotor SDM saja (skills) — seperti pada human capital paradigma tetapi juga pada pengembangan pribadi yang bermoral, beretika dan mandiri berkat kehalusan rasa dan kebeningan suara hati nuraninya (Character).
\end{abstract}

Kata Kunci: human capital paradigm, human growth paradigm, knowledge, skills, dan Character.

\begin{abstract}
This paper is based on two theories that emphasize the paradigm of how the role of education for development. The first is the paradigm of human capital (human capital paradigm), which is influenced by classical economic theory, the Neo Liberal. This theory views and places human resources only as a factor of production. The second is the paradigm that is oriented towards human resource development with the direction of long-term goals, namely human growth paradigm. It is a paradigm that builds HR with an education system that not only relies on intellectual intelligence and psychomotor skills of HR (skills), such as on human capital paradigms but also on personal development that is moral, ethical and independent thanks to the subtlety of sense and silence of conscience conscience (Character).
\end{abstract}

Keywords: human capital paradigm, human growth paradigm, knowledge, skills, dan Character.

\section{PENDAHULUAN}

Perjalanan sejarah bangsa - bangsa menunjukkan bahwa negara yang memfokuskan pembangunan berdimensi manusia telah mampu berkembang dan maju dengan laju yang cukup pesat, meskipun Negara tersebut tidak memiliki kekayaan sumberdaya alam (SDA) yang berlimpah. Penekanan pada investasi manusia 
diyakini merupakan basis dalam meningkatkan produktivitas faktor produksi secara total. Tanah, tenaga kerja, modal fisik bisa saja mengalami diminishing returns, namun pengetahuan tidak. Alfred Marshall (dalam Basri, F, 2009) pernah mengatakan:

"although nature is subject to diminishing returns, man is subject to increasing returns-Knowledge is our most powerful engine of production; it enables us to subdue nature and satisfy our wants".

Bagi Indonesia, globalisasi yang dianalogkan sebagai "era kebebasan adalah realita yang tidak dapat dihindari la merupakan sebuah realita yang dapat menjadi hambatan dan tantangan. Serta dapat juga dapat menjadi peluang guna terealisasinya cita-cita pembangunan nasional bangsa Indonesia seperti yang diamanatkan dalam pembukaan Undang-Undang Dasar 1945, yaitu "masyarakat yang adil dan makmur".

Kajian ini akan menjelaskan dan mengkajia bagaimana peningkatan kualitas manusia sebagai agen produktif harus menjadi tujuan utama dari setiap kebijakan pembangunan, Untuk hal tersebut maka penulis mnawarkan sebuah pemikiran dalam makalah / kertas karya ini yaitu : Human Growth Paradigm sebagai Strategi Pengembangan Sumberdaya Manusia (SDM ) Indonesia di Era Millenial.

\section{PERMASALAHAN PEMBANGUNAN SUMBERDAYA MANUSIA (SDM)}

Yang sering menjadi sebuah pertanyaan apa yang menjadi permasalahan pokok dan struktural Indonesia yang menyebabkan perekonomiannya tidak optimal untuk mencapai kemakmurannya? Disini kita kemungkinan besar akan berbeda pendapat. Tiap orang akan punya argumen sendiri tergantung dari sisimana ia melihatnya atau mengkajinya, Pendapat yang berlainan satu sama lain itu lumrah terjadi. Karena itu, mari kita tidak berdebat, saling belajar dan bertukar pikiran, demi memperoleh pendapat, atau sekurang-kurangnya pemahaman, yang lebih baik. Bertolak dari semangat itu, izinkan penulis mengajukan pendapat tentang apa saja yang menjadi masalah struktural kita.

Sekurang-kurangnya ada tiga masalah besar yang menurut hemat penulis merupakan yang harus segera dibenahi. Andaikan saja ketiga masalah struktural dapat diatasi dengan baik, penulis merasa yakin situasi dan signifikan akan lebih baik, sehingga jauh lebih siap menghadapi dinamika domestik dan global di segala bidang, 
tanpa membelokkan dasar kita guna turut mengupayakan agar kita kian mendekati situasi segera baik singkat namun penuh makna oleh. Pembukaan UUD 45, yang sekaligus menjadi tujuan hakiki penciptaan apa yang dinamakan "Indonesia", yakni suatu bangsa dan negara yang merdeka, bersatu, berdaulat, adil, dan makmur.

Dalam tulisan ini menyajikan gambaran selintas dari tiga masalah struktural itu, dan sejauh mana hal-hal itu telah dan akan mengikat kaki kita sehingga sulit bergerak maju, serta majulah masalah struktural pertama (pendidikan). Adapun ketiga masalah struktural itu adalah :

1. Minimnya sumber daya manusia yang berkualitas yang terutama disebabkan oleh masih lemahnya kinerja pendidikan (berupa intelektualitas siswa di semua tingkatan) maupun pendidikan itu sendiri.

2. Keterbatasan infrastruktur, baik itu infrastruktur fisik maupun non fisik.

3. Kelemahan kerangka kelembagaan (institutional framework) atau bisa pula disebut infrastruktur lunak (soft infrastructure). Dalam definisi ini maka infrastruktur fisik dan non fisik dapat pula disebut sebagai infrastruktur keras (hard infrastructure).

Satu catatan perlu diberikan di sini. Masalah struktural kedua dan ketiga di atas dapat pula dipandang sebagai satu rumpun permasalahan yang sama. Dalam hemat penulis, apa disebut sebagai kerangka kelembagaan sesungguhnya juga merupakan suatu entitas infrastruktur sehingga keseluruhan masalah struktural Indonesia dapat pula dipilah menjadi dua bagian besar, yakni keterbatasan sumber daya manusia (dengan titik berat pada (pendidikan) dan keterbatasan infrastruktur dalam berbagai bentuknya.

\section{NEW PARADIGMA PEMBANGUNAN BERWAWASAN MANUSIA}

Dalam praktek pembangunan di banyak negara, setidaknya pada tahap awal pembangunan, umumnya berfokus pada peningkatan produksi, Meskipun banyak varian pemikiran, pada dasarnya kata kunci dalam pembangunan adalah pembentukan modal. Oleh karena itu, strategi pembangunan yang dianggap aksalerasi pertumbuhan ekonomi dengan mengundang modal asing dan melakukan industrialisasi. Peranan 
sumberdaya manusia (SDM) dalam strategi semacam ini hanyalah sebagai instrumen " atau salah satu produksi " saja. Manusia ditempatkan sebagai posisi instrumen dan merupakan subyek dari pembangunan, Titik berat pada nilai produksi produktivitas telah mereduksi manusia sebagai penghambat maksimisasi kepuasan maupun maksimisasi keuntungan.

\section{KAITAN PEMBANGUNAN SUMBER DAYA MANUSIA DAN PERTUMBUHAN EKONOMI}

Yang menjadi salah satu indikator yang digunakan untuk mengukur sejauh mana pembangunan manusia seutuhnya telah membuahkan hasil di suatu negara adalah Indeks Pembangunan Manusia (HDI, Human Development Index). Pada dasarnya HDI digunakan untuk mengklasifikasikan apakah sebuah negara adalah negara maju, negara berkembang atau negara terbelakang. Data-data pada Tabel I, Peraga II, pada intinya menegaskan hal yang sama, yakni betapa HDI Indonesia relatif rendah kalau dibandingkan dengan negara-negara lain, dan di masa mendatang terancam akan kian tertinggal karena laju pertumbuhan HDI-nya juga tidak setinggi yang dicapai oleh negara-negara lain.

Dalam perkembangannya, HDI juga digunakan sebagai patokan umum yang mencerminkan sejauh mana kualitas sumber daya manusia di berbagai negara. Skor diberikan pada angka antara 0 hingga 1, dan semakin besar angkanya (kian mendekati angka 1), semakin tinggi HDI-nya, dan semakin baik hasil yang dibuahkan pembangunan manusia yang ada di negara bersangkutan. Secara implisit, HDI menegaskan adanya hubungan yang sangat kuat dan langsung antara kondisi pendidikan dan kesehatan di satu pihak, dengan tingkat pertumbuhan ekonomi di pihak lain. Alur pemikirannya dapat disaksikan pada Peraga I. Di situ ditunjukkan bahwa antara pertumbuhan ekonomi, kualitas kesehatan, dan pendidikan senantiasa terdapat hubungan timbal balik secara berkesinambungan, Dalam analisis umum yang biasa diberikan UNDP, dinyatakan bahwa kenaikan 1 persen skor HDI akan mendorong kenaikan produktivitas tenaga kerja hingga 2,5 persen, dan hal ini akan segera disusul dengan kenaikan tambahan pertumbuhan pendapatan perkapita nasional sebesar 1,5 persen. 
Tentang tingkat pertumbuhan ekonomi Indonesia yang mengalami pasang surut. Masalah yang dihadapi Indonesia ternyata bukan semata-mata pada besaran (sekian persen) tingkat pertumbuhan ekonomi tahunan, melainkan lebih pada kualitas pertumbuhan ekonomi itu sendiri. Yang lebih relevan untuk dibahas di sini adalah kondisi kesehatan dan pendidikan, Kalau keduanya hendak ditentukan mana yang lebih penting, maka penulis cenderung pada pendidikan (SDM) karena hal itulah yang paling menentukan karakter dan kualitas pribadi individu. Berdasarkan analisis penulis, masalah kesehatan, apalagi masalah pendidikan, selama ini memang berkaitan langsung dengan berbagai keterpurukan yang ada di negara kita. Lebih jauh, penulis menyimpulkan bahwa lemahnya kondisi sumber daya manusia itulah yang menjadi akar dari berbagai keterpurukan di Indonesia, termasuk tentunya di bidang ekonomi.

Berdasarkan data resmi UNDP (Tabel 1), pada tahun 2004 (datanya diumumkan pada akhir tahun 2006) HDI Indonesia meraih skor 0,697 dan menempati urutan ke-108 dari total 177 negara yang diteliti. Di lingkungan Asia Tenggara saja Indonesia tercecer jauh ketinggalan dari Singapura yang berada di urutan paling tinggi (no, 25 di dunia), disusul Brunei Darussalam, Malaysia, Thailand, dan Filipina, Peraga 1 yang khusus menyoroti; perkembangan HDI di Asia Tenggara plus Cina memperlihatkan betapa Indonesia memang tertatih-tatih dalam soal pembangunan manusia sehingga mencatat skor yang relatif rendah dari tahun ke tahun. Bahkan Vietnam yang sebelumnya selalu "menemani" Indonesia di tingkat bawah kini mulai beringsut dan bergerak lebih maju. Jika ini terjadi, maka kita pasti malu dan prihatin karena Vietnam baru dapat membenahi diri sejak tahun 1975.

Tabel 1 juga menunjukkan bahwa untuk HDI 2004 (2006), Indonesia hanya unggul setingkat di atas Vietnam yang berada pada peringkat 107. Namun berdasarkan data HI terbaru, yakni HDI tahun 2005 yang datanya baru diumumkan pada tanggal 27 November 2007 (data terbaru untuk tahun 2006 baru diumumkan akhir tahun 2008), Vietnam malahan sudah menduduki peringkat ke-105 dari 177 negara, atau melompat naik empat anak tangga lebih tinggi sehingga meninggalkan Indonesia yang memperoleh skor HDI lebih tinggi dari tahun sebelumnya, yakni sebesar 0,728, namun hanya cukup mengantar ke satu tingkat lebih tinggi sehingga Indonesia hanya berada di peringkat 105 . Seandainya trend yang ada berlanjut, maka kemungkinan besar di tahun-tahun mendatang peringkat HDI Indonesia akan kian tertinggal dari 
negara-negara lain anggota pertama ASEAN maupun negara-negara yang baru belakangan menjadi anggota ASEAN. Kedudukan Indonesia tampak lebih memprihatinkan kalau dibandingkan dengan negara-negara yang memegang skor tertinggi di dunia dalam soal HDI (lihat Tabel 1). Tentunya bukan suatu prestasi membanggakan kalau peringkat Indonesia hanya di atas negara-negara baru (Timor Leste), negara terbelakang (Papua Nugini), atau negara yang sampai sekarang masih diguncang oleh konflik bersenjata seperti halnya Kamboja.

Tabel. 1

\section{Perkembangan Historis HDI Indonesia dan Sejumlah Negara}

\begin{tabular}{|c|c|c|c|c|c|c|c|}
\hline NEGARA & $\mathbf{1 9 7 5}$ & $\mathbf{1 9 8 0}$ & $\mathbf{1 9 8 5}$ & $\mathbf{1 9 9 0}$ & $\mathbf{1 9 9 5}$ & $\mathbf{2 0 0 0}$ & $\mathbf{2 0 0 5}$ \\
\hline Islandia & 0.868 & 0.890 & 0.899 & 0.918 & 0.923 & 0.947 & 0.968 \\
\hline Amerika serikat & 0.870 & 0.890 & 0.904 & 0.919 & 0.931 & 0.942 & 0.951 \\
\hline RRC & 0.530 & 0.559 & 0.595 & 0.634 & 0.691 & 0.732 & 0.777 \\
\hline India & 0.419 & 0.450 & 0.487 & 0.521 & 0.551 & 0.578 & 0.619 \\
\hline Singapura & 0.729 & 0.762 & 0.789 & 0.827 & 0.865 & - & 0.922 \\
\hline Malaysia & 0.619 & 0.662 & 0.696 & 0.725 & 0.763 & 0.790 & 0.811 \\
\hline Thailand & 0.615 & 0.654 & 0.679 & 0.712 & 0.745 & 0.761 & 0.781 \\
\hline Filiphina & 0.655 & 0.688 & 0.692 & 0.721 & 0.739 & 0.758 & 0.771 \\
\hline Vietnam & - & - & 0.590 & 0.620 & 0.672 & 0.711 & 0.733 \\
\hline Indonesia & 0.471 & 0.533 & 0.585 & 0.626 & 0.670 & 0.692 & 0.728 \\
\hline Kamboja & - & - & - & - & 0.540 & 0.547 & 0.598 \\
\hline Papua Nugini & 0.431 & 0.462 & 0.481 & 0.495 & 0.532 & 0.544 & 0.560 \\
\hline Timur Leste & - & - & - & - & - & - & 0.514 \\
\hline
\end{tabular}


Gambar. 1.

\section{Kaitan Timbal Balik antara Pembangunan Manusia dan Pertumbuhan Ekonomi}

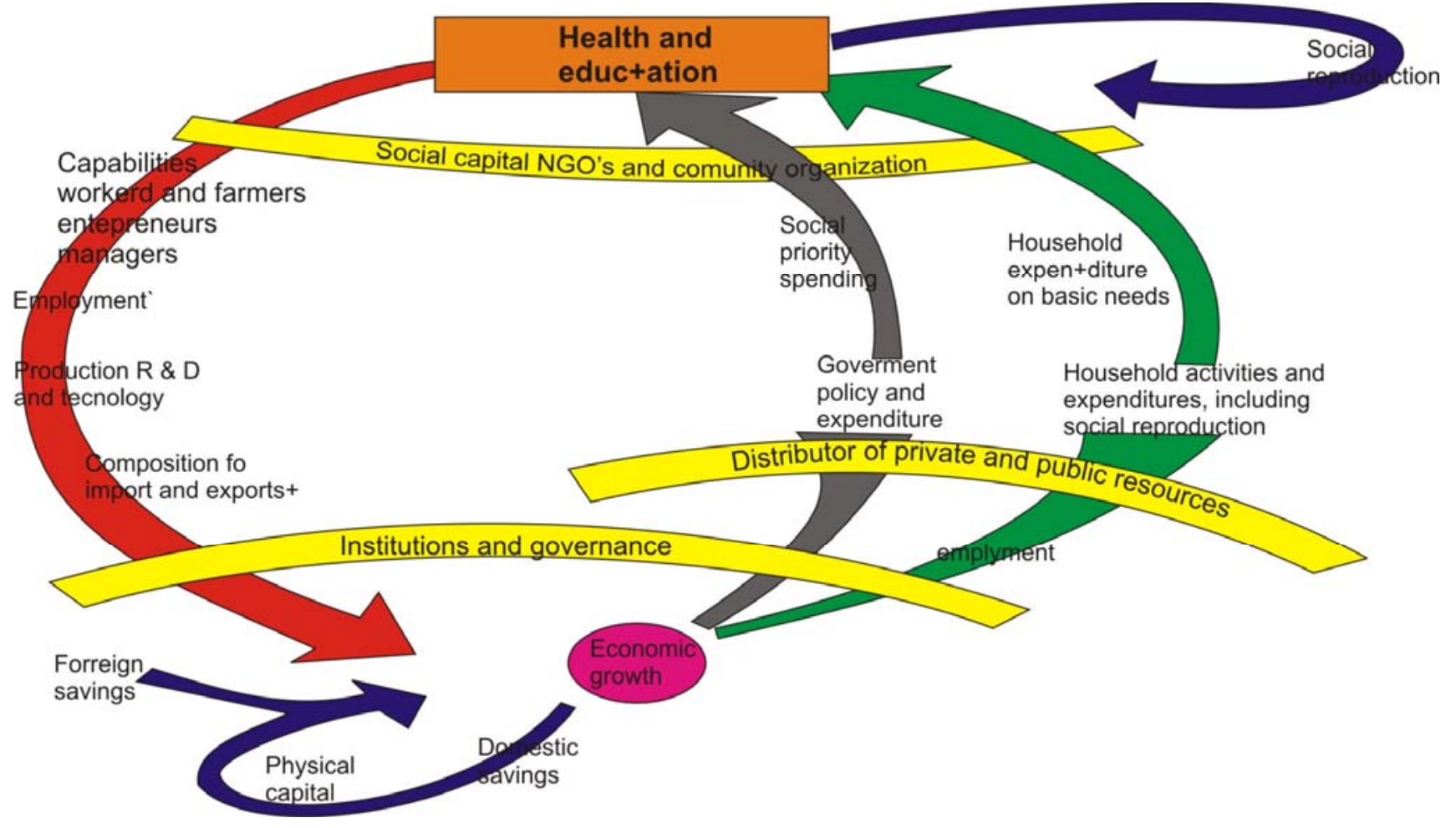

\section{STRATEGI PENGEMBANGAN SUMBERDAYA MANUSIA (SDM)}

Ada dua teori yang mempertegas tentang paradigma bagaimana peran pendidikan bagi pembangunan. Yang pertama, adalah paradigma sumber daya manusia (human capital paradigm), yang dipengaruhi oleh teori ekonomi klasik, Neo Liberal. Teori ini memandang dan menempatkan sumber daya manusia hanya sebagai faktor produksi, yang selanjutnya dianggap sebagai instrumen terstruktur untuk mencapai tujuan-tujuan produksi yang ekonomis dan mekanistik, demi kepentingan kaum kapitalis. Oleh karena itu banyak pengamat mengkritisi sistem pendidikan berideologi paradigma SDM tersebut, dengan menganggap bahwa paradigma tersebut hanya akan melahirkan SDM yang mengalami reduksi nalar, yaitu SDM yang "rationality without reason", yang oleh Mills cenderung disebut "cheerful robot", yaitu SDM yang mempunyai rasio tetapi tanpa akal budi dan kehilangan daya kreatif. 
Jadi suatu strategi pendidikan yang tidak akan mengembangkan SDM sebagaimana mestinya.

Paradigma pengembangan pendidikan yang kedua adalah paradigma yang berorientasi pengembangan SDM dengan arah tujuan jangka panjang, yaitu human growth paradigm. Merupakan suatu paradigma yang membangun SDM dengan sistem pendidikan yang bukan hanya mengandalkan kecerdasan intelektual (knowledge) serta keterampilan psikomotor SDM saja (skills) — seperti pada human capital paradigma tetapi juga pada pengembangan pribadi yang bermoral, beretika dan mandiri berkat kehalusan rasa dan kebeningan suara hati nuraninya (Character).

Dalam kaitannya dengan era globalisasi, interaksi antar-manusia akan ada pada tatanan yang sudah begitu tinggi, sehingga keunggulan kompetitif suatu bangsa tidak hanya ditentukan oleh keunggulan kompetitif produk-produk ekonominya di pasar internasional misalnya, melainkan juga oleh keluhuran budi atau pribadi manusiamanusianya. Dalam kaitan ini maka dapat dianggap bahwa sistem pendidikan yang didasari pada paradigma pembangunan manusia, human growth akan lebih unggul dibanding dengan strategi paradigma SDM, karena daripadanya akan lahir SDM yang Work Class sifatnya, seperti yang dikemukakan oleh Moss-Kanter.

Dalam perspektif manajemen, guna mengimplementasikan strategi pengembangan pendidikan yang berasas pada human growth paradigm tersebut seperti termuat dalam visi dan misi UU Pendidikan Nasional hal tersebut dapat dilakukan melalui tiga strategi utama, yakni pentingnya reorientasi, restrukturisasi dan strategi aliansi terhadap sistem pendidikan nasional. Reorientasi berarti pentingnya menemukenali faktor-faktor yang dapat menentukan keberhasilan tujuan dan sasaran pendidikan, yang disesuaikan dengan keadaan dan kebutuhan. Kemudian, restrukturisasi berarti pentingnya melakukan langkah-langkah konkrit untuk mengoperasionalkan strategi-strategi pengembangan pendidikan yang telah ditetapkan. Sedangkan strategi aliansi, berarti bahwa pentingnya mengembangkan pendidikan dalam kerangka sebagai tugas dan tanggung jawab bersama dari seluruh pelaku yang terlibat.

Untuk kepentingan tersebut maka« penting dilakukan "reengineering" manajemen pendidikan nasional di setiap waktu, dengan melakukan tiga langkah utama, yaitu reorientasi, restrukturisasi dan aliansi. 
Dalam aspek ekonomi dan peningkatan produksi kualitas Sumberdaya manusia (SDM) diarahkan dalam rangka peningkatan produksi. Inilah yang disebut sebagai pengembangan SDM dalam kerangka production centered development (Tjokrowinoto, 1996; 28-29). dipahami apabila topik pembicaraan dalam perspektif paradigma pembangunan yang semacam itu terbatas pada masalah pendidikan, peningkatan ketrampilan kesehatan, link and match, dan sebagainya. Kualitas manusia yang meningkat merupakan prasyarat utama dalam proses produksi dan memenuhi tuntutan masyarakat industrial.

Alternatif lain dari strategi pembangunan manusia adalah apa yang disebut sebagai people-centered development atau putting people first (Korten, 198' 201). Artinya, manusia (rakyat) merupakan tujuan utama dari pembangunan, dalam kehendak serta kapasitas manusia merupakan sumberdaya yang paling penting

\section{PENUTUP}

Dari uraian penulis diatas dapat ditarik kesimpulan bahwa paragdigma pembangunan manusia berkaiatan erat dengan pendidikan, kesehatan dan pertumbuhan ekonomi suatu daerah dan negara.

\section{DAFTAR PUSTAKA}

Basri, F dan Haris M. 2009. “ Laskap Ekonomi Indonesia: Kajian dan Renungan Terhdap Masalah - Masalah Struktural, Tranformasi Baru, dan Prosfek Perekonomian Indonesia., Penerbit : Kencana Prenada Media Group. Jakarta.

Boediono, 1997. Pendidikan dan Perubahan Sosial Ekonomi. Aditya Media

Hamid, Edy Suandi dan Hendrie Anto, 2000, Ekonomi Indonesia Memasuki Millenium III, UII Press.

Marzuki., 2010, “ Analisis Perekonomian Nasional dan Internasional” Edisi 2 Penerbit : Mitra Wacana Media. Jakarta.

Misbahuddin, 2009,Human Growth Paradima Sebagai Strategi Pembangunan Sumberdaya Manusia Indonesia di Era Milenium III,Jurnal, Makassar.

Tambunan,.M.2010, “ Menggagas Perubahan Pendekatan Pembangunan : Menggerakkan Kekuatan Lokal dalam Globalisasi Ekonomi” 
JURNAL APLIKASI Manjemen \& Kewirausahaan MASSA RO

Volume 1, No. 1, Pebruari 2019

Penerbit : Graha Ilmu. Jakarta.

W.I.M. Poli., 2010 : Materi Perkuliahan : Perekonomian Indonesia “ Ilmu Ekonomi (S3) PPS Unhas. Makassar Makassar. 